Check for updates

Cite this: RSC Adv., 2019, 9, 29120

\title{
Protective effect of ginger (Zingiber officinale) against PCB-induced acute hepatotoxicity in male rats
}

\author{
Khedher Ahd, ${ }^{a}$ Sabah Dhibi, (D) *ab Sarra Akermi, ${ }^{\text {ab }}$ Hafsia Bouzenna, ${ }^{\text {ab }}$ \\ Noura Samout, ${ }^{\mathrm{ab}}$ Abdelfattah Elfeki ${ }^{\mathrm{b}}$ and Najla Hfaiedh ${ }^{\mathrm{ab}}$
}

After absorption by the organism, polychlorinated biphenyls (PCBs) cross cellular membranes and pass into blood vessels and the lymphatic system. It is generally in the liver, adipose tissues, brain and skin that we find the strongest concentrations of PCBs. Herbal medicine remains as a discipline intended to treat and to prevent certain functional disorders and/or pathologies caused by oxidative stress, which can be induced by pesticides, medicines or pollutants. The objective of this study is to verify the toxic and oxidative effects of PCBs and to investigate the protective effect of ginger (Zingiber officinale) in the liver of male rats of the "Wistar" strain. These rats are divided into 6 groups: a control group (T), two groups treated with PCB at two different concentrations $\left(P_{1}\right.$ and $\left.P_{2}\right)$, a group treated with ginger extract $(G)$, a group pretreated with ginger extract and then injected with the first concentration of $P C B s\left(P_{1} G\right)$, and a group pretreated with ginger and then injected with the second concentration of PCBs $\left(P_{2} G\right)$. The results showed that the administration of PCBs led to an increase in the relative weight of the liver, and a significant increase in all of the hepatic biomarker levels (glucose, cholesterol, triglycerides, AST, ALT, and $(D H)$ in the serum. Furthermore, an increase in the rate of lipid peroxidation and a decrease in the antioxidant enzyme activities (catalase, superoxide dismutase and glutathione peroxidase) were observed under the influence of PCBs in the liver. The histological test showed that the PCBs induced hepatocyte vacuolization, prominent and peripheralized nuclei, hepatocellular hypertrophy and turgor of the vein in the centriacinar regions. Pretreatment with ginger extract restored all of the biochemical and oxidative parameters to the normal values and reduced the injuries caused by the PCBs. In conclusion, in our experimental conditions, ginger effectively protects the liver against the hepatotoxic effects induced by PCBs.

rsc.li/rsc-advances

and are found in certain fatty tissues in humans, including human milk. ${ }^{4-7}$

In the body, polychlorinated biphenyls cross cellular membranes and pass into the blood vessels and lymphatic system; then, they are stored in the liver, adipose tissues, brain and skin. ${ }^{8,9}$ PCBs can undergo anaerobic reductive dechlorination and lead to the formation of less chlorinated congeners. ${ }^{10}$ The highly chlorinated PCBs accumulate more in the body than the lower chlorinated ones, but they are considered less toxic. ${ }^{11,12}$ The biotransformation of PCBs could also occur via enzyme-mediated oxidation, which leads to the formation of hydroxylated polychlorinated biphenyls (OH-PCBs). ${ }^{11-13} \mathrm{OH}^{-}$ PCBs are considered to be more toxic than their parent PCBs and could lead to the disruption of thyroid hormone metabolism. ${ }^{14}$

Some research work has shown that PCBs as endocrine disruptors and enzyme inducers can perturb metabolism. ${ }^{15}$ Exposure to PCBs has harmful effects on the nervous system, ${ }^{16}$ reproduction because of the hormonal disruption, alteration in thyroid function, and the development of the immune system,

${ }^{a}$ Unity of Macromolecular Biochemistry and Genetics Faculty of Sciences, Sidi Ahmed Zarrouk, 2112, Gafsa, Tunisia.E-mail: sabahdhibi7@gmail.com

${ }^{b}$ Laboratory of Environmental Physiopathology, Valorization of Bioactive Molecules and Mathematical Modeling, Faculty of Sciences of Sfax, Road Soukra km 3.5, PB no 1171-3000, Sfax, Tunisia 
and PCBs also have carcinogenic effects. ${ }^{17,18}$ Most of the past studies also reported that PCBs induce oxidative stress by the high generation of free radicals such as $\mathrm{O}_{2}{ }^{-}$and $\mathrm{H}_{2} \mathrm{O}_{2} \cdot{ }^{19}$ These ROS are thought to contribute to lipid peroxidation, DNA damage and protein degradation. ${ }^{20}$ Indeed, in physiological conditions, there is a perfect balance between the production of reactive oxygen species (ROS) and antioxidant defense systems. Thus, oxidative stress will be defined when there is a serious imbalance between pro-oxidants and antioxidants in favor of the latter. ${ }^{21}$

The liver, being the primary site for xenobiotic detoxification, is the principal target organ for toxic effects induced by environmental pollutants, including PCBs. ${ }^{22}$ It has been shown that polychlorinated biphenyls disrupt the function of the liver. Commercial mixtures of PCBs and their congeners have been discovered to be hepatically carcinogenic by their induction of mono-oxygenase cytochrome P450-dependent pathways in the liver. ${ }^{23}$ This is due to the activity of tumor initiation of the lower chlorinated congeners and tumor promoting activity of highly chlorinated PCB congeners. ${ }^{24}$ Furthermore, it was found that $\mathrm{PCB}_{3}$ is responsible for the induction of gene mutation, which is a typical characteristic of tumor initiation, in the liver and lungs of rats by increasing ROS levels. ${ }^{25}$

For several years, the wealth of medicinal plants was the remedy and solution to health problems and increasing attention has been paid to the protective effects of these natural antioxidants on drug-induced toxicities.

Ginger, Zingiber officinale, has been used for 6000 years, and it is the panacea of Asian medicine. It has been used to treat transport and pregnancy nausea, has been used as an antioxidant, and has antimicrobial and antifungal properties, in addition to its culinary uses. ${ }^{26,27}$ Several studies have shown that gingerol, the active ingredient of ginger, has anti-inflammatory and analgesic activities. ${ }^{28}$ Besides, "in vitro" it has been shown that Zingiber officinale has an antioxidant action and can protect against free radicals in animals, ${ }^{29}$ hence its anticancer activity. ${ }^{30}$ In addition, it was shown that ginger acts on the liver to reduce cholesterol biosynthesis, stimulate its conversion into bile acids and increase its fecal excretion. ${ }^{31}$ Therefore, we assume that ginger can prevent against the hepatotoxic effects of PCBs.

In this study, we investigated whether pretreatment with an aqueous extract of ginger for 6 weeks could prevent PCBinduced hepatotoxicity in male Wistar rats. The serum levels of glucose, cholesterol, triglycerides, lactate dehydrogenase (LDH), aspartate aminotransferase (AST) and alanine aminotransferase (ALT), and activities of antioxidant enzymes (catalase, SOD, GPx, TBARS) were measured in the liver.

\section{Materials and methods}

\subsection{Preparation of the aqueous extract}

Commercialized powder of Zingiber officinale (ZOE) was purchased from a local market, homogenized in boiling distilled water and soaked for about $24 \mathrm{~h}$. Then the mixture was filtered, and the filtrates were stored in a refrigerator for subsequent analysis.

\subsection{PCB sample}

In this study, we used Aroclor 1260 provided from an electricity company's dead stock.

\subsection{Phytochemical studies of Zingiber officinale extract}

Determination of total phenolic content. The total phenolic content of ZOE $\left(1 \mathrm{mg} \mathrm{ml}^{-1}\right)$ was determined using the FolinCiocalteu method..$^{32}$ Briefly, $250 \mu$ of the extract was mixed with $0.125 \mathrm{ml}$ of Folin-Ciocalteu reagent (diluted 10 times with distilled water) and $1 \mathrm{ml}$ of $7.5 \%$ saturated sodium carbonate (w/v). After $2 \mathrm{~h}$ of incubation at $45{ }^{\circ} \mathrm{C}$, the absorbance was measured at $765 \mathrm{~nm}$ by a Shimadzu 1240 model spectrophotometer. The amount of total phenolics is expressed as gallic acid equivalents (GAE, mg gallic acid per $\mathrm{g}$ of $\mathrm{ZOE}$ ) through a calibration curve ranging from $0-100 \mu \mathrm{g} \mathrm{ml} \mathrm{ml}^{-1}\left(R^{2}=0.9927\right)$ and all tests were carried out in triplicate.

Determination of total flavonoid content. The total flavonoid content in ZOE ( $1 \mathrm{mg} \mathrm{ml}^{-1}$ ) was determined using a method described by Djeridane et al. ${ }^{33}$ A volume of $500 \mu \mathrm{l}$ of $\mathrm{ZOE}$ was mixed with $150 \mu \mathrm{l}$ of $\mathrm{NaNO}_{2}$ and $150 \mu \mathrm{l}$ of $\mathrm{AlCl}_{3} \cdot 6 \mathrm{H}_{2} \mathrm{O}$ methanolic solution (2\%). Then, after $15 \mathrm{~min}$ of incubation at room temperature, the absorbance of the mixture was measured at $430 \mathrm{~nm}$. The amount of total flavonoid content is expressed as rutin equivalents ( $\mathrm{mg}$ RE per $\mathrm{g}$ of $\mathrm{ZOE}$ ) through the calibration curve ranging from $0-400 \mu \mathrm{g} \mathrm{ml} \mathrm{m}^{-1}\left(R^{2}=0.9644\right)$ and all tests were carried out in triplicate.

Determination of total condensed tannins (proanthocyanidin). The total condensed tannins of ZOE were determined by the vanillin- $\mathrm{H}_{2} \mathrm{SO}_{4}$ method. ${ }^{34} 3 \mathrm{ml}$ of vanillin methanolic (4\%) was added to $400 \mu \mathrm{l}$ of $\mathrm{ZOE}\left(1 \mathrm{mg} \mathrm{ml}^{-1}\right)$ and $1.5 \mathrm{ml}$ of concentrated sulfuric acid. The mixture was then incubated for $15 \mathrm{~min}$ at room temperature and the absorbance was measured at $430 \mathrm{~nm}$. The amount of proanthocyanidin is expressed as catechin equivalents ( $\mathrm{mg} \mathrm{CE}$ per $\mathrm{g} \mathrm{ZOE}$ ). The calibration curve ranged from $0-350 \mu \mathrm{g} \mathrm{ml}^{-1}\left(R^{2}=0.9978\right)$.

\subsection{In vitro antioxidant activity of $\mathrm{ZOE}$}

DPPH radical scavenging activity. The method reported by Grzegorczyk et $a .^{35}$ was used to estimate the free radical scavenging activity of ZOE with the DPPH radical assay. $1 \mathrm{ml}$ of various concentrations of $\mathrm{ZOE}\left(0-400 \mu \mathrm{g} \mathrm{ml}{ }^{-1}\right)$ was mixed with $1 \mathrm{ml}$ of a methanolic solution of DPPH $(0.1 \mathrm{mM})$ and incubated for $30 \mathrm{~min}$ at $37{ }^{\circ} \mathrm{C}$. A second range of concentrations was prepared with $1 \mathrm{ml}$ of methanol to serve as a control solution. Ascorbic acid was used as a reference in the same concentration range as the test extract. Then, the absorbance of each sample was measured at $517 \mathrm{~nm}$. All the analyses were done in triplicate. The ZOE antioxidant activity was calculated as follows:

$$
\mathrm{ARA} \%=1-\left[\left(A_{\text {sample }}-A_{\text {control }}\right) / A_{\mathrm{DPPH}}\right] \times 100
$$

where $A_{\mathrm{DPPH}}$ is the absorbance of the DPPH solution without sample extract, $A_{\text {sample }}$ is the absorbance of the sample extract mixed with DPPH solution and $A_{\text {control }}$ is the absorbance of the sample extract tested without $\mathrm{DPPH}$. The $\mathrm{IC}_{50}$ value is the 
concentration of ZOE capable of scavenging $50 \%$ of the DPPH radicals.

Ferric reducing antioxidant power. The capacity of the $\mathrm{ZOE}$, in different concentrations $\left(0-500 \mu \mathrm{g} \mathrm{ml}^{-1}\right)$, to reduce the ferric ion $\left(\mathrm{Fe}^{3+}\right)$ present in the $\mathrm{K}_{3}\left[\mathrm{Fe}(\mathrm{CN})_{6}\right]$ complex to a ferrous ion $\left(\mathrm{Fe}^{2+}\right)$ was evaluated by the method described by Chu et al. ${ }^{36}$ Briefly, $2.5 \mathrm{ml}$ of potassium phosphate buffer $(0.1 \mathrm{M}$, pH 6) and $2.5 \mathrm{ml}$ of potassium ferricyanide $(1 \% \mathrm{w} / \mathrm{v})$ were mixed with $1 \mathrm{ml}$ of the extract $\left(0-500 \mu \mathrm{g} \mathrm{ml} \mathrm{m}^{-1}\right)$. The reaction mixture was incubated for $20 \mathrm{~min}$ at $50{ }^{\circ} \mathrm{C}$ in a water bath. Subsequently, $2.5 \mathrm{ml}$ of trichloroacetic acid solution $(10 \%, \mathrm{w} / \mathrm{v})$ was added, and the mixture was centrifuged at $3000 \mathrm{rpm}$ for $10 \mathrm{~min}$. Then, $2.5 \mathrm{ml}$ of the supernatant was mixed with $2.5 \mathrm{ml}$ of distilled water and $0.5 \mathrm{ml}$ of $\mathrm{FeCl}_{3}$ and finally incubated at $20{ }^{\circ} \mathrm{C}$ for $30 \mathrm{~min}$. The absorbance of the samples was measured at $700 \mathrm{~nm}$. Ascorbic acid was used as a standard for comparison and the tests were carried out in triplicate.

\subsection{Acute toxicity test}

The ZOE was investigated in toxicity studies. A total of 30 rats were divided randomly into 5 groups supplemented orally with gradually increasing concentrations $(100 \mathrm{mg}$ to $1000 \mathrm{mg}$ per rat). The animals were directly observed for toxic symptoms, after the first $4 \mathrm{~h}$ of dosing. After $24 \mathrm{~h}$, the surviving animals were maintained under daily observation for two weeks.

Live subject statement. The experimental protocol was approved by the Faculty of Ethics Committee in our institution with ethics approval number 1204. The animals were maintained in accordance with the International Guidelines for the Care and Use of Living Animals in Scientific Investigations (Council of European Communities 1986).

\subsection{Animal treatments}

Three-month-old Wistar male rats, about $111 \mathrm{~g}$ in body weight, fed on $15 \%$ protein food (SNA, Sfax, Tunisia), were kept in a breeding farm, at $22{ }^{\circ} \mathrm{C}$, with a stable hygrometry, under a constant photoperiod.

These rats were divided into 6 batches each containing 6 rats:

- Group T, which served as the control group.

- Group G, which was treated by drinking $200 \mathrm{mg}$ per $\mathrm{kg}$ b.w. of the aqueous ginger extract ${ }^{37}$ throughout the duration of the treatment.

- Two groups $\mathrm{P}_{1}$ and $\mathrm{P}_{2}$, which were treated with PCBs at two different concentrations $\left(\mathrm{P}_{1}=470 \mathrm{mg}\right.$ per $\mathrm{kg}$ of b.w. and $\mathrm{P}_{2}=$ $980 \mathrm{mg}$ per kg of b.w.) by using intra-gastric intubation,,$^{\mathbf{3 8}}$ for 7 and 5 days, respectively.

- Two groups $\mathrm{P}_{1} \mathrm{G}$ and $\mathrm{P}_{2} \mathrm{G}$, which were pretreated with the aqueous extract of ginger in drinking water for 6 weeks and then administered the PCBs at concentrations $\mathrm{P}_{1}$ and $\mathrm{P}_{2}$ for 7 and 5 days, respectively.

The animals were weighed daily and after 49 days of treatment they were sacrificed by cervical disruption. The liver was quickly removed and weighed, a portion was stored at $-80{ }^{\circ} \mathrm{C}$ until analysis and a portion was fixed in formalin immediately for histopathological examination. Blood was centrifuged and serum aliquots were stored at $-80{ }^{\circ} \mathrm{C}$.

\subsection{Preparation of the liver extracts}

About $1 \mathrm{~g}$ of liver was cut into small pieces and homogenized in $2 \mathrm{ml}$ of ice-cold Tris buffer (TBS, pH 7,4) using a crusher (homogenizing Ultra-Turax), and then centrifuged at $9000 \mathrm{rpm}$ for $15 \mathrm{~min}$ at $4{ }^{\circ} \mathrm{C}$. The supernatants (S1) were collected and stored at $-80{ }^{\circ} \mathrm{C}$ until use.

\subsection{Biochemical assays}

Assays of serum markers. Serum levels of glucose, total cholesterol and triglycerides, and the activities of lactate dehydrogenase ( $\mathrm{LDH})$, alanine transaminase (ALT) and aspartate transaminase (AST) were assayed using commercial diagnostic kits (Spinreact Biomaghreb, Tunisia) (http:// www.spinreact.com).

Estimation of lipid peroxidation. According to Yagi, ${ }^{39}$ the level of lipid peroxidation was measured as thiobarbituric acid reactive substances (TBARS). For the assay, $125 \mu \mathrm{l}$ of supernatant (S1) was mixed with $175 \mu$ of $20 \%$ trichloroacetic acid containing $1 \%$ butylhydroxy-toluene (BHT) and centrifuged $\left(1000 \times g, 10 \mathrm{~min}, 4^{\circ} \mathrm{C}\right)$. Then, $200 \mu \mathrm{l}$ of the supernatant $(\mathrm{S} 2)$ was mixed with $40 \mu \mathrm{l}$ of $\mathrm{HCl}(0.6 \mathrm{M})$ and $160 \mu \mathrm{l}$ of thiobarbituric acid $(0.72 \mathrm{mM})$ and the mixture was heated at $80^{\circ} \mathrm{C}$ for $10 \mathrm{~min}$.

The absorbance was measured at $530 \mathrm{~nm}$. The amount of TBARS was calculated using an extinction coefficient of 156 $\mathrm{mM}^{-1} \mathrm{~cm}^{-1}$ and expressed in nmol $\mathrm{mg}^{-1}$ of protein.

Catalase activity. Catalase activity was measured according to Aebi. ${ }^{40}$ The reaction mixture $(1 \mathrm{ml})$ contained $100 \mathrm{mM}$ phosphate buffer (pH 7), $100 \mathrm{mM} \mathrm{H}_{2} \mathrm{O}_{2}$ and $20 \mu \mathrm{l}$ (about 1$1.5 \mathrm{mg}$ of protein) of liver homogenate. $\mathrm{H}_{2} \mathrm{O}_{2}$ decomposition was followed by measuring the decrease in absorbance at $240 \mathrm{~nm}$ for $1 \mathrm{~min}$. The enzyme activity was calculated using an extinction coefficient of $0.043 \mathrm{mM}^{-1} \mathrm{~cm}^{-1}$ and expressed in international units (IU), i.e., in $\mu \mathrm{mol} \mathrm{H}_{2} \mathrm{O}_{2}$ destroyed per min per mg protein, at $25^{\circ} \mathrm{C}$.

Superoxide-dismutase activity. The total ( $\mathrm{Cu}-\mathrm{Zn}$ and $\mathrm{Mn}$ ) superoxide-dismutase (SOD) activity was determined by measuring its ability to inhibit the photo-reduction of nitroblue tetrazolium (NBT). ${ }^{\mathbf{4 1}}$ One unit of SOD represents the amount inhibiting the photo-reduction of NBT by $50 \%$. The activity was expressed as units per $\mathrm{mg}$ protein, at $25{ }^{\circ} \mathrm{C}$.

Glutathione peroxidase activity (GPx). GPx activity was assayed according to the method of Flohe \& Gunzler. ${ }^{42}$ The activity was expressed as $\mu \mathrm{mol}$ of GSH oxidized per min per $\mathrm{g}$ of protein, at $25^{\circ} \mathrm{C}$.

Protein content. Protein content in tissue extracts was determined according to Lowry's method $^{\mathbf{4 3}}$ using bovine serum albumin as the standard.

\subsection{Histopathological examination}

Formalin-fixed livers were processed routinely, embedded in paraffin, sectioned at 3-4 $\mu \mathrm{m}$ and stained with hematoxylin and eosin (H\&E). An expert in histopathological evaluation ${ }^{44}$ examined the slides. 


\subsection{Statistical analysis}

Two independent experiments were performed. Data were expressed as means \pm standard deviation (SD). Statistical significance was assessed using Student's $t$-test. $p \leq 0.05$ was considered significant.

\section{Results}

\subsection{Acute toxicity test}

The tested animals were administered with different doses of ginger extract (100-1000 $\mathrm{mg} \mathrm{kg}^{-1}$ ). The data of the acute toxicity test showed no toxicity or lethality observed up to $1000 \mathrm{mg} \mathrm{kg}^{-1}$. In this study, a dose of $200 \mathrm{mg} \mathrm{kg}^{-1} \mathrm{BW}$ was chosen to investigate the antioxidant and hepatoprotective activities of the aqueous extract of $Z$. officinale in experimental animals.

\subsection{Phytochemical studies of ZOE}

The phytochemical studies of $\mathrm{ZOE}$ revealed a significant amount of polyphenols (179.5 $\pm 2.47 \mathrm{mg}$ GAE per $\mathrm{g}$ DW ZOE) and to a lesser degree flavonoids and condensed tannins (59.1 \pm $0.7 \mathrm{mg}$ RE per $\mathrm{g}$ DW ZOE and $28.38 \pm 5.66 \mathrm{mg}$ CE per $\mathrm{g}$ DW ZOE, respectively) (Table 1 ).

\subsection{In vitro antioxidant capacity}

DPPH radical scavenging activity. The antiradical activity of the Zingiber officinale extract, in vitro, against the DPPH radical is shown on Fig. 1. Indeed, as the concentration of the extract increases, the anti-DPPH activity increases also until reaching a maximum concentration of $0.4 \mathrm{mg} \mathrm{mL}^{-1}$. The antioxidant capacity was determined from $\mathrm{IC}_{50}$, which corresponds to the concentration necessary to reduce $50 \%$ of the DPPH radicals. The $\mathrm{IC}_{50}$ of the $Z$. officinale extract is mathematically calculated and valued as $79.70 \pm 0.27 \mu \mathrm{g} \mathrm{mL}^{-1}$, which is significantly lower than that of ascorbic acid used as a positive control (19.41 \pm $2.71 \mu \mathrm{g} \mathrm{mL}^{-1}$ ) (Table 2).

Ferric reducing antioxidant power. As shown in Fig. 2, ginger has the capacity to reduce $\mathrm{Fe}^{3+}$ to $\mathrm{Fe}^{2+}$, at different concentration ranges. The reducing power of $\mathrm{ZOE}$ and its concentration are dose-dependent. It was found to be $0.129 \pm 0.008$ absorbance units at $500 \mu \mathrm{g} \mathrm{mL}{ }^{-1}$ with the effective concentration $\mathrm{EC}_{50}$ being $19.4 \pm 1.23 \mu \mathrm{g} \mathrm{mL} \mathrm{m}^{-1}$. This activity appeared significantly $(p<0.05)$ lower compared with that of the positive control (ascorbic acid), which was $0.52 \pm 0.003$ absorbance units at $500 \mu \mathrm{g} \mathrm{mL}{ }^{-1}$ with an $\mathrm{EC}_{50}$ of $0.47 \pm 0.002 \mu \mathrm{g} \mathrm{mL} \mathrm{m}^{-1}$.

\subsection{Liver weight}

After sacrifice of the rats, the livers were weighed and the relative weight was estimated. The results showed an important increase in liver relative weight in all PCB-treated groups: $\mathrm{P}_{1}, \mathrm{P}_{2}$, $\mathrm{P}_{1} \mathrm{G}$ and $\mathrm{P}_{2} \mathrm{G}(+77 \%, 68 \%, 87 \%$ and $54 \%$, respectively). There was no significant improvement noticed even with ginger pretreatment (Fig. 3).

\subsection{Serum markers of cell damage}

Lactate dehydrogenase (LDH), aspartate aminotransferase (AST) and alanine aminotransferase (ALT) are released into the blood when certain organs or tissues, particularly the liver and heart, are injured. As shown in Fig. 4, PCB treatment induced a significant increase in the serum levels of LDH, AST and ALT $\left(+33 \%, 42 \%\right.$ and $64 \%$, respectively) in $\left(\mathrm{P}_{1}\right)$ and $\left(\mathrm{P}_{2}\right)$ rats, as compared to controls $(\mathrm{T})$. These effects were significantly decreased in the PCB-treated rats drinking ginger extract $\left(\mathrm{P}_{1} \mathrm{G}\right.$ and $\mathrm{P}_{2} \mathrm{G}$ groups $)(-26 \%, 20 \%$ and $19 \%$, respectively) compared to the PCB-treated groups (Fig. 4).

The serum levels of glucose $(+24 \%)$, triglycerides $(+180 \%)$ and total cholesterol ( $+98 \%)$ were also found to be significantly increased in $\left(\mathrm{P}_{1}\right)$ and $\left(\mathrm{P}_{2}\right)$ rats, as compared to controls. However, these levels were significantly decreased in the rats pretreated with ginger extract $\left(\mathrm{P}_{1} \mathrm{G}\right.$ and $\left.\mathrm{P}_{2} \mathrm{G}\right)$ (Table 3).

\subsection{Estimation of lipid peroxidation levels (TBARS) in liver extract}

In this study, we showed that the administration of PCBs (at concentrations $\mathrm{P}_{1}$ and $\mathrm{P}_{2}$ ) induces an important increase in the TBARS rates $(+117 \%$ and $140 \%$, respectively) in the liver as compared to control rats $(\mathrm{T})$. However, in rats pretreated with singer extract $\left(\mathrm{P}_{1} \mathrm{G}\right.$ and $\left.\mathrm{P}_{2} \mathrm{G}\right)$, the rates of TBARS decreased and the results are comparable with those obtained for the control rats (T) (Fig. 5).

\subsection{Changes of antioxidant enzyme activities in liver extracts}

PCB treatment induced a significant increase $(+142 \%)$ in SOD activity in the liver of $\left(\mathrm{P}_{1}\right)$ and $\left(\mathrm{P}_{2}\right)$ rats and about a $-53 \%$ decrease in CAT and GPx activities (Fig. 5). However, the ginger extract pretreatment $\left(\mathrm{P}_{1} \mathrm{G}\right.$ and $\mathrm{P}_{2} \mathrm{G}$ groups $)$ showed important changes in the activities of these enzymes $(-45 \%$ decrease in SOD activity, $+88.5 \%$ and $63.5 \%$ increase, respectively, in CAT and GPx activities).

Table 1 The Zingiber officinale extract phytochemical composition

\begin{tabular}{|c|c|c|c|}
\hline & Total phenolics $^{a}$ (mg GAE per g DW) & Total flavonoids $^{b}$ (mg RE per g DW) & Total condensed tannins ${ }^{c}(\mathrm{mg}$ CE per $\mathrm{g}$ DW) \\
\hline
\end{tabular}




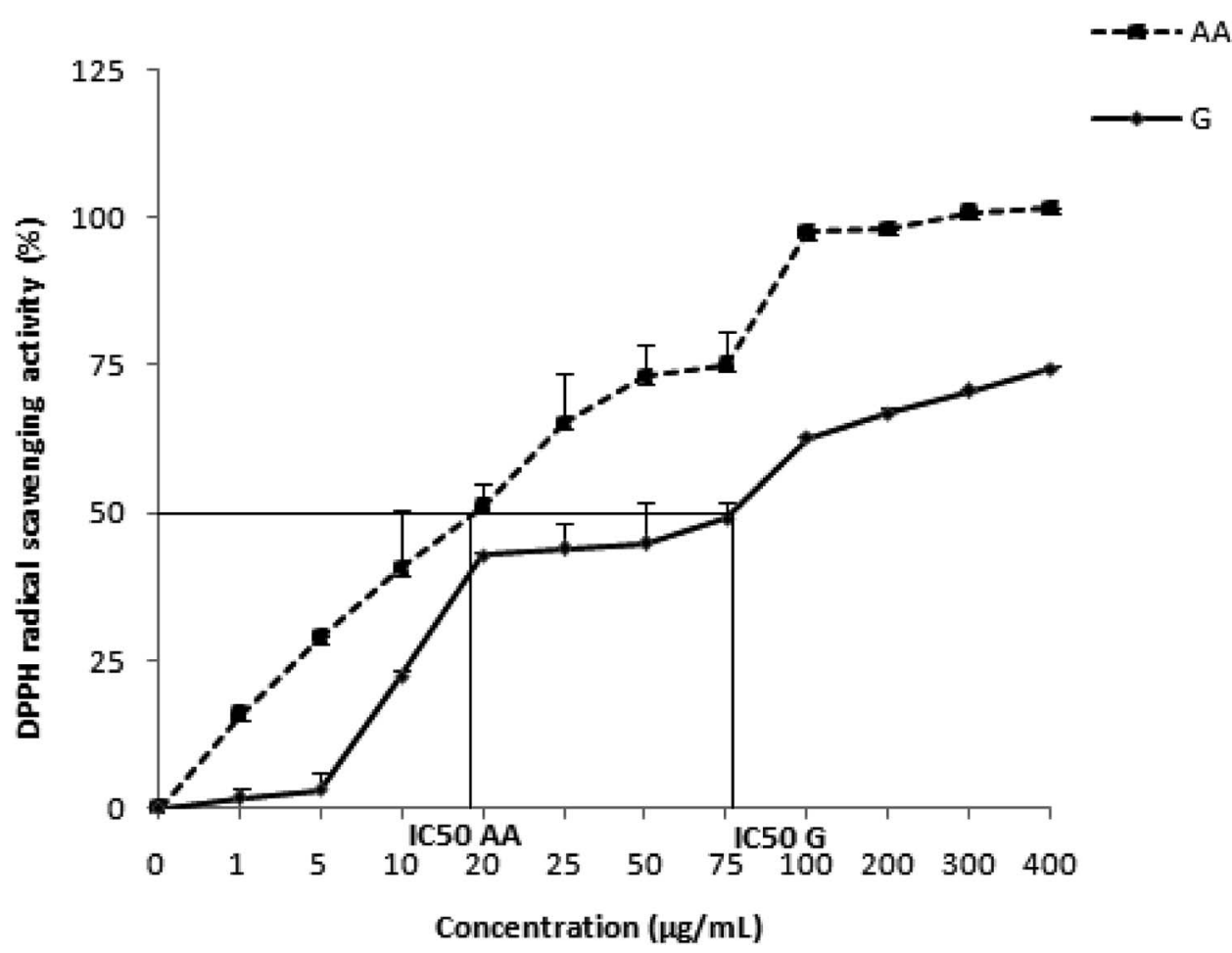

Fig. 1 The antiradical activity of Zingiber officinale against the radical DPPH. Values are represented as mean $\pm \operatorname{standard~deviation~}(n=3)$.

Table 2 The Zingiber officinale extract antioxidant capacity ${ }^{a}$

\begin{tabular}{lll}
\hline & $\mathrm{DPPH}\left(\mathrm{IC}_{50}, \mu \mathrm{g} \mathrm{mL}{ }^{-1}\right)$ & $\mathrm{FRAP}\left(\mathrm{EC}_{50}, \mathrm{mg} \mathrm{mL}^{-1}\right)$ \\
\hline Zingiber officinale & $79.70 \pm 0.27$ & $19.4 \pm 1.23$ \\
Ascorbic acid & $19.41 \pm 2.71$ & $0.47 \pm 0.002$
\end{tabular}

${ }^{a}$ Values are expressed as mean \pm standard deviation $(n=3)$.

\subsection{Liver histopathological changes}

Histological examination showed that the PCBs (for both concentrations of $470 \mathrm{mg} \mathrm{kg}{ }^{-1}$ and $940 \mathrm{mg} \mathrm{kg}^{-1}$ ) lead to an increase in the size of the hepatic lobules due to hepatocyte hypertrophy characterized by large areas of cytoplasmic pallor (hydropic degeneration), mild vacuolation of hepatocytes (arrows, c and d, Fig. 6), prominent and peripheralized nuclei,

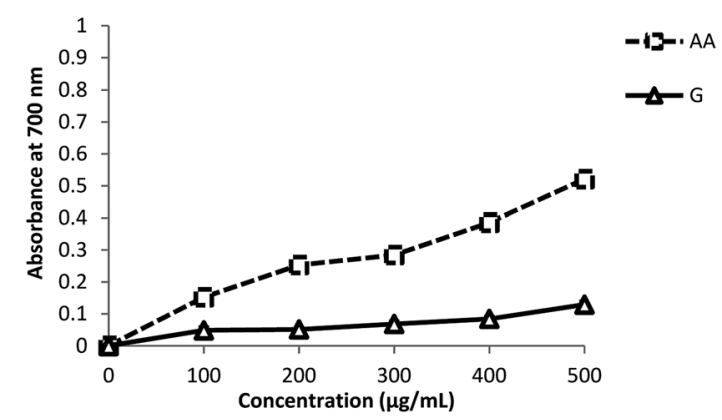

Fig. 2 The reducing power of Zingiber officinale and ascorbic acid by the FRAP assay. Values are expressed as mean \pm standard deviation $(n=3)$. and hypertrophy and turgor in the central vein (CL, c and d, Fig. 6). These changes were moderately improved in gingerpretreated rats (e and $\mathrm{f}$ ). In the control (a) and ginger groups (b), there was no evidence of hepatic abnormality; we observed mild cytoplasmic clearing without vacuolization and with centrally located nuclei consistent with glycogen.

\section{Discussion}

In this study, we intended to determine the toxic effect of polychlorinated biphenyls (PCBs) on hepatic function, and to verify the protective effects of ginger extract against the toxicity induced by PCBs.

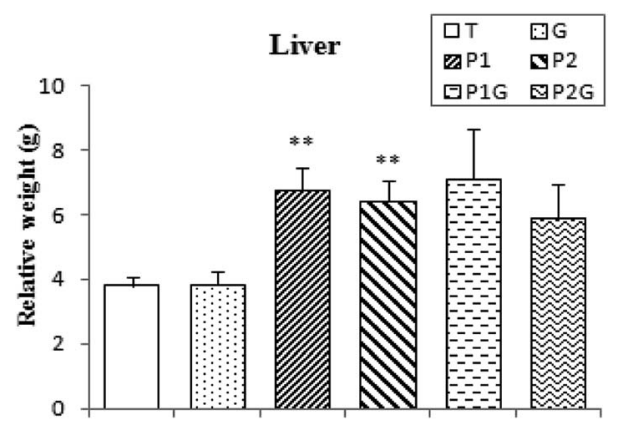

Fig. 3 Liver relative weight of control rats $(T)$, rats consuming ginger $(G)$, rats treated for 7 and 5 days $\left(P_{1}\right.$ and $P_{2}$, respectively) and rats pretreated with ginger for 6 weeks $\left(P_{1} G\right.$ and $\left.P_{2} G\right)$. Values correspond to the mean of 6 measurements \pm SD. Student test: $* *(p \leq 0.01)$ indicates significant differences between $\left(P_{1}\right.$ and $\left.P_{2}\right)$ and control rats $(T)$. 


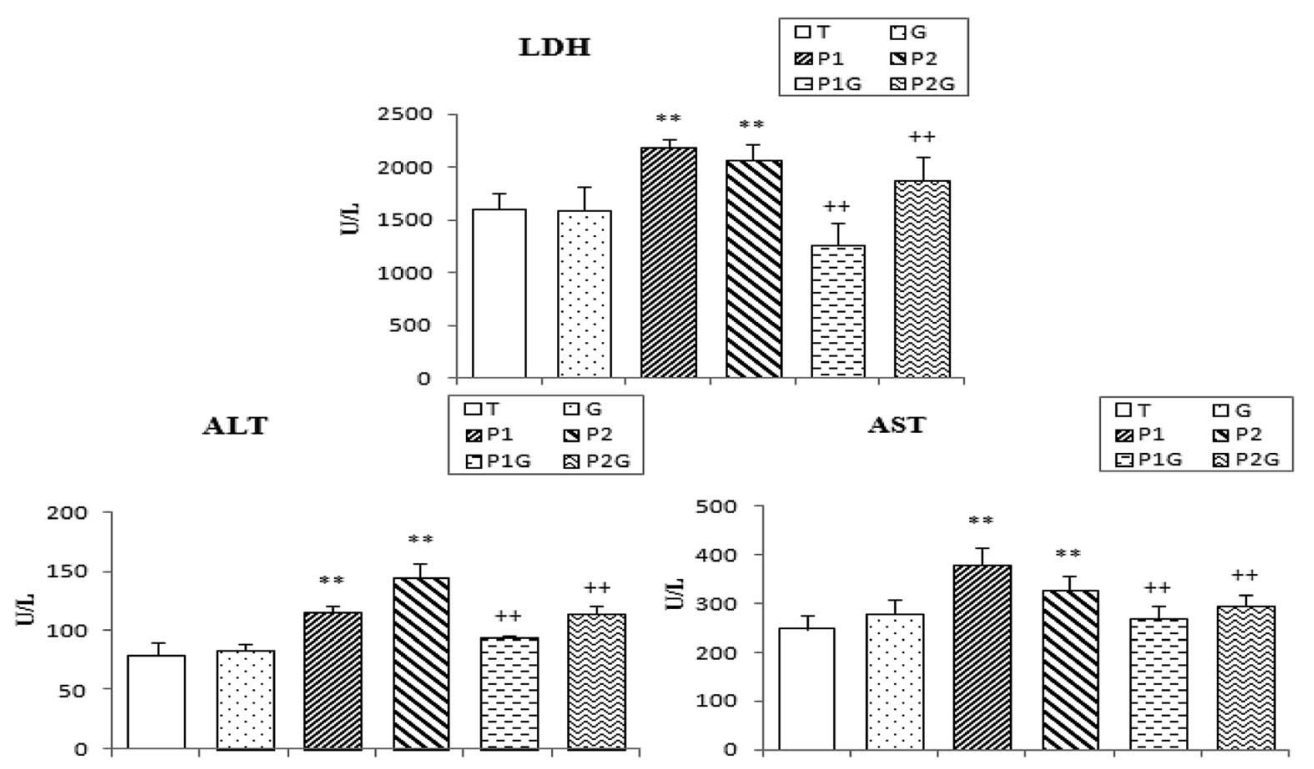

Fig. 4 Activities of lactate dehydrogenase (LDH), alanine aminotransferase (ALT) and aspartate aminotransferase (AST) in control rats (T), rats consuming ginger $(G)$, rats treated for 7 and 5 days $\left(P_{1}\right.$ and $P_{2}$, respectively) and rats pretreated with ginger for 6 weeks $\left(P_{1} G\right.$ and $\left.P_{2} G\right)$. Values correspond to the mean of 6 measurements \pm SD. Student test: ** $(p \leq 0.01)$ indicates significant differences between $\left(P_{1}\right.$ and $\left.P_{2}\right)$ and control rats (T). ${ }^{++}(p \leq 0.01)$ indicates significant difference between $\left(P_{1} G\right.$ and $\left.P_{2} G\right)$ and $\left(P_{1}\right.$ and $\left.P_{2}\right)$ rats.

In the animal study, we found that the oral administration of PCBs to male rats from the "Wistar" strain induced liver hypertrophy. In accordance with our study, Lai et al. ${ }^{45}$ explained this liver hypertrophy by the accumulation of lipids due to disruption of hepatic lipid intake and metabolism.

The PCB treatment induced a highly significant increase in the serum levels of glucose, cholesterol and triglycerides, which is associated with an increase in the hepatic biomarkers AST, ALT and LDH. This could be explained by the strong accumulation of PCBs in the liver and the severe alteration of hepatocytes. Indeed, the transaminases (AST and ALT), which are involved in protein renewal and the synthesis of new peptides, strongly affect the metabolism due to their inhibition by PCBs. Consistent with our results, Pereira \& $\mathrm{RaO}^{46}$ found that the administration of PCBs (Clophen A60) at $2.8 \mathrm{mg}$ per $\mathrm{kg}$ of b.w. per day significantly increased the level of glucose, LDH, cholesterol and triglycerides. In addition, our results are harmonized with other studies reporting negative effects of PCBs in the liver, such as that by Wang et al. ${ }^{47}$ AST, being a primarily mitochondrial enzyme, allows us to deduce that, at the cellular level, there was an increase in respiratory burst and mitochondrial involvement in the hepatocytes of rats treated with PCB. Pereira \& $\mathrm{RaO}^{46}$ explained the increase of hepatic biomarkers with the increase of lipid peroxidation that could affect mitochondrial function and the leakage of mitochondrial enzymes due to the injury of the mitochondrial membranes.

After 49 days of treatment, we observed in rats pretreated with ginger aqueous extract $\left(\mathrm{P}_{1} \mathrm{G}\right.$ and $\left.\mathrm{P}_{2} \mathrm{G}\right)$ that the toxicity of PCB was greatly reduced. The aqueous extract of ginger decreased significantly the AST, ALT, cholesterol, triglyceride, glucose and LDH levels. Several studies clearly reinforce our results, showing the hepatoprotective effect of ginger against liver toxicity induced by ethanol, carbon tetrachloride, bromobenzene and acetaminophen, accompanied by a significant decrease of AST and ALT. ${ }^{48-51}$ It is the same for the hypocholesterolemic effect of ginger, which is probably due to the inhibition of cellular synthesis of cholesterol. The possible mechanism of the plant to reduce serum triglycerides is due to

Table 3 Serum levels of glucose, triglycerides and cholesterol in control rats $(T)$, rats consuming ginger $(G)$, rats treated for 7 and 5 days $\left(P_{1}\right.$ and $P_{2}$, respectively) and rats pretreated with ginger for 6 weeks $\left(P_{1} G \text { and } P_{2} G\right)^{a}$

\begin{tabular}{|c|c|c|c|c|c|c|}
\hline Glucose $\left(\mathrm{mmol} \mathrm{L}^{-1}\right)$ & $4.8 \pm 0.98$ & $5.36 \pm 0.86$ & $\begin{array}{l}6.84 \pm 0.46^{* *} \\
+42.5 \%\end{array}$ & $\begin{array}{l}5.04 \pm 0.05 \\
+5 \%\end{array}$ & $\begin{array}{l}5.58 \pm 0.73^{+} \\
-18 \%\end{array}$ & $5.1 \pm 0.14$ \\
\hline Total cholesterol $\left(\mathrm{mmol} \mathrm{L}^{-1}\right)$ & $1.56 \pm 0.14$ & $1.82 \pm 0.08$ & $\begin{array}{l}3.04 \pm 0.53^{* *} \\
+95 \%\end{array}$ & $\begin{array}{l}3.14 \pm 0.24^{* *} \\
+101 \%\end{array}$ & $\begin{array}{l}2.19 \pm 0.73^{++} \\
-28 \%\end{array}$ & $\begin{array}{l}1.88 \pm 0.11^{++} \\
-40 \%\end{array}$ \\
\hline
\end{tabular}

${ }^{a}$ Student test: ${ }^{* *}(p \leq 0.01)$ indicates significant differences between $\left(\mathrm{P}_{1}\right.$ and $\left.\mathrm{P}_{2}\right)$ and control rats $(\mathrm{T}) .{ }^{++}(p \leq 0.01)$ indicates significant difference between $\left(\mathrm{P}_{1} \mathrm{G}\right.$ and $\left.\mathrm{P}_{2} \mathrm{G}\right)$ and $\left(\mathrm{P}_{1}\right.$ and $\left.\mathrm{P}_{2}\right)$ rats. Values correspond to the mean of 6 measurements $\pm S D$. 

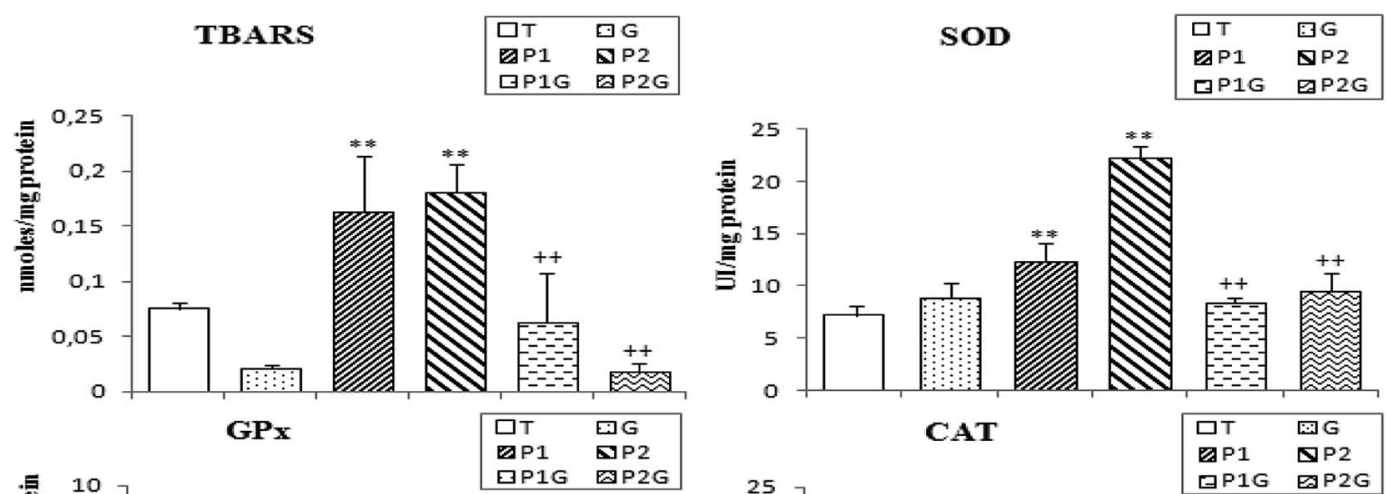

the increase in the expression and activity of the lipoprotein lipase enzyme in the vessels. This enzyme increases the breakdown of triglycerides in the blood vessels and reduces the blood levels of triglycerides. ${ }^{52}$ Ginger also inhibits hepatic fatty acid and triglyceride synthesis by lowering key enzyme activity. ${ }^{53}$ In the research of Heeba \& Abd-Elghany, ${ }^{54}$ it was also shown that ginger stimulates the conversion of cholesterol into bile acids, and increasing the excretion of cholesterol and phospholipids in the stools after taking ginger can also be considered as a potential mechanism for the effects of ginger in reducing serum cholesterol levels. ${ }^{55,56}$ In the study of Gao et al., ${ }^{57}$ it was shown that ginger improves insulin sensitivity in the body,
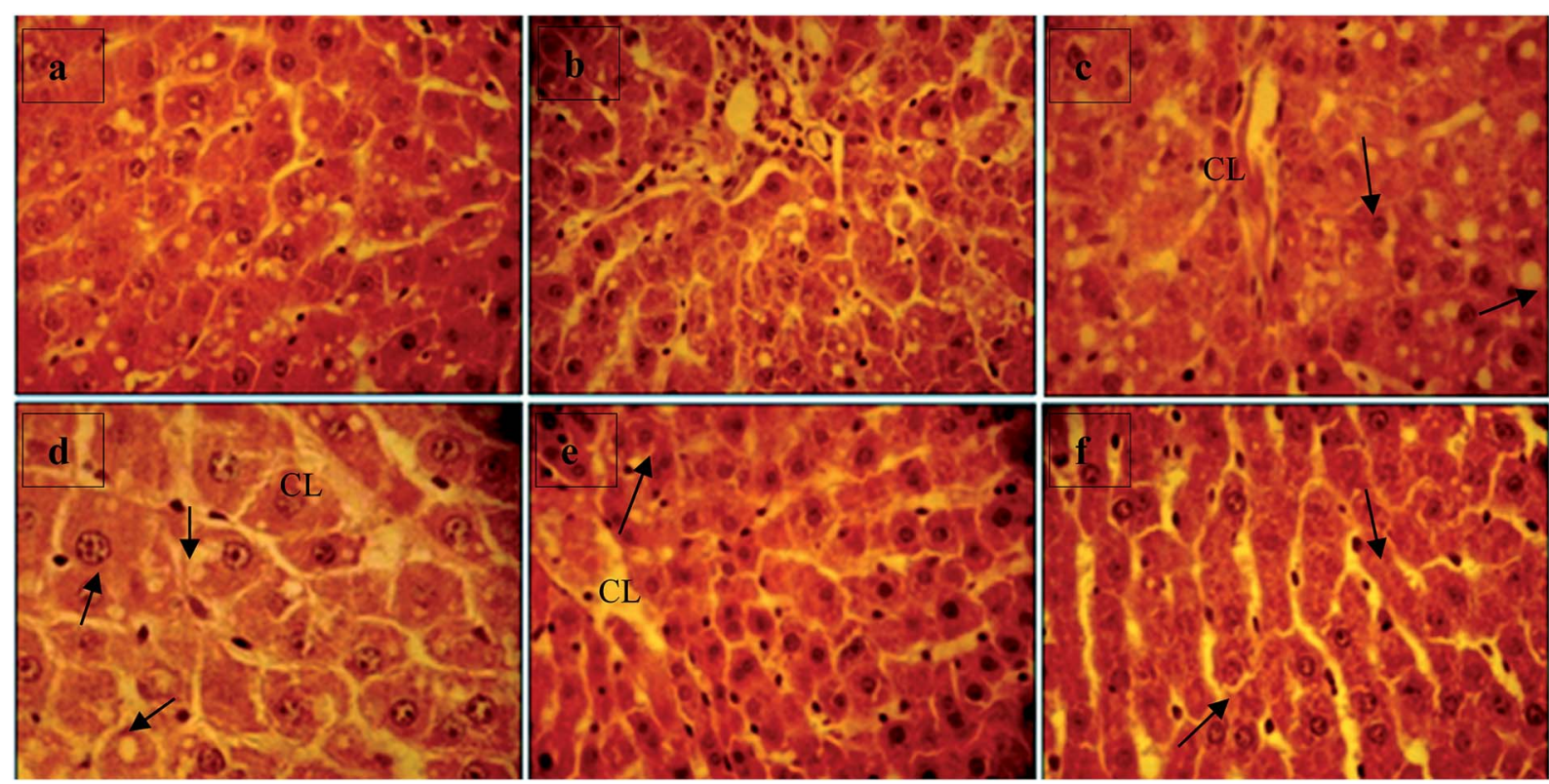

Fig. 6 Liver histopathological changes induced by exposure to PCBs. Representative photographs showing (a) a control rat ( $T$ ) liver section, (b) a liver section from a rat consuming ginger $(G),(c)$ and $(d)$ liver sections from $P C B$-treated rats $\left(P_{1}\right.$ and $\left.P_{2}\right)$ and $(e)$ and (f) liver sections from gingerpretreated rats $\left(P_{1} G\right.$ and $\left.P_{2} G\right)$. H\&E staining; (a), (b) and (d)-(f) $40 \times$ objective; (c) $100 \times$ objective. CL: turgescence of the centrilobular vein. Arrows: vacuolization of hepatocytes, prominent and peripheralized nuclei and hypertrophy and turgor of the central vein. 
which may explain the mechanism of the decrease in blood glucose levels in rats pretreated with ginger.

Our experimental study showed that the induction of oxidative stress by PCBs has been demonstrated by the highly significant increase of TBARS in liver tissues. We found that the levels of lipid peroxidation are responsible for the formation of lipid hydroperoxides in membranes, leading to lesions in the membrane structure and inactivation of enzyme membrane binding. ${ }^{58}$ Research by Twaroski et al. ${ }^{59}$ showed that the toxic manifestations induced by PCBs may be associated with the high production of ROS and the initiation and self-propagating reaction of lipid peroxidation. The oxygen radicals react with poly-unsaturated fatty acid residues in the phospholipids resulting in the production of excessive amounts of products, which can damage proteins and DNA. In fact, PCBs may interact with hydrogen peroxide to form hydroxyl radicals, which are the most active form of ROS in biological systems.

It seems quite clear that the presence of ginger reduced the TBARS in pretreated rats $\left(\mathrm{P}_{1} \mathrm{G}\right.$ and $\left.\mathrm{P}_{2} \mathrm{G}\right)$. This urged us to deduce that ginger plays a protective role against oxidative stress induced by PCBs. The research of Rajkumar \& $\mathrm{Ra}^{60}$ showed an important inhibition of lipid peroxidation by dehydrozingerone, which is a synthetic analogue of zingerone. It is important to note that dietary ginger concomitant to $1 \% \mathrm{w} / \mathrm{w}$ during the administration of malathion (20 ppm) for 4 weeks significantly attenuated lipid peroxidation in the liver. ${ }^{61}$

The high lipid peroxidation may also be due to decreased activities of catalase and superoxide dismutase, which are scavenger enzymes of free radicals. In our study, we found that PCBs increased the activity of superoxide dismutase and decreased the catalase and glutathione peroxidase activities. Several studies have associated changes in the activity of superoxide dismutase with the reduced synthesis, high degradation or inactivation of this enzyme. ${ }^{16,20,62}$ Other studies have investigated the increase in superoxide dismutase activity and they explained these results by the increase of the concentration of superoxide anions $\left(\mathrm{O}_{2}{ }^{-}\right)$, which causes an increase in the concentration of $\mathrm{H}_{2} \mathrm{O}_{2}$ due to the inhibition of catalase and glutathione peroxidase, as they are the responsible enzymes for scavenging $\mathrm{H}_{2} \mathrm{O}_{2}$. In the work of Venkataraman et al., ${ }^{16}$ the decrease in glutathione peroxidase activity in rats treated with PCBs is correlated to the reduction of the substrate, meaning reduced glutathione (GSH) level and high peroxide level. In other research studies, the decrease observed in our results is evaluated by decreased synthesis and/or inactivation of the enzyme. $^{20}$

However, the administration of ginger as a pretreatment (200 mg per $\mathrm{kg}$ of b.w.) for 6 weeks restored the activities of antioxidant enzymes. This could be explained by the presence of several antioxidant compounds in ginger, such as gingerols, shogaol derivatives, ketones, phenolics, flavonoids and volatile oils. $^{58}$ [6]-Gingerol as the major constituent of ginger has been shown to exert an inhibitory effect on xanthine oxidase, the enzyme responsible for the generation of reactive oxygen species. ${ }^{63}$ This antioxidant activity of ginger extract is explained by the results found in our phytochemical study, which revealed significant levels of polyphenols and a lesser amount of flavonoids and tannins, which is correlated with the findings of Gabr et al. ${ }^{64}$ These antioxidant substances are well known to protect the body against free radicals. The antioxidant activity of $Z$. officinale aqueous extract was evaluated in vitro using the DPPH and FRAP tests. Our results showed important reducing properties due to the presence of compounds that reduce the ferricyanide complex of $\mathrm{Fe}^{3+}$ to the ferrous $\left(\mathrm{Fe}^{2+}\right)$ form by donating a proton. In addition, the ginger aqueous extract exhibits a significant scavenging activity based on the reduction of the stable and free radical DPPH (purple color) thanks to the hydrogen atoms existing on the antioxidant contents of the ZOE. Our observations are consistent with those demonstrated by Gabr et al. ${ }^{64}$ These antioxidant potentials of the ginger extract might be due to its richness in polyphenols and flavonoids. These bioactive compounds are known by their redox properties and might play an important role in chelating transition metals and scavenging free radicals. ${ }^{65}$ The studies of Shanmugam et al. ${ }^{58}$ showed that the activities of antioxidant enzymes SOD and GPx were improved in the liver tissue of animals pretreated with an ethanolic extract of ginger at a concentration of $100 \mathrm{mg}$ per $\mathrm{kg}$ b.w. compared to animals exposed to bromobenzene. The same research team reported that the extract of ginger decreases the activity of cytochrome P450 by reducing the metabolism of bromobenzene into reactive metabolites.

Histological examination showed that the PCBs (at both concentrations of $470 \mathrm{mg} \mathrm{kg}^{-1}$ and $940 \mathrm{mg} \mathrm{kg}^{-1}$ ) induced vacuolization of hepatocytes, prominent and peripheralized nuclei and hypertrophy and turgor of the central vein. The results of this study are consistent with the works of Lai $e t a l .^{45}$ and Wang et al., ${ }^{47}$ which showed severe changes in hepatocytes with an increase in the size of the lobules and capsular irregularity. However, the aqueous extract of ginger slightly attenuated these cytological manifestations. This has been demonstrated in the studies of Heeba \& Abd-Elghany, ${ }^{54}$ showing that the administration of ginger plays an important role in reducing liver damage and preserves the integrity of the hepatocyte membranes.

In conclusion, it seems that ginger is able to protect the liver against oxidative stress and biochemical manifestations induced by polychlorinated biphenyls. The high protection capacity of ginger could be due to its content of antioxidant phytochemicals, which neutralize the high production of free radicals generated by the PCBs.

\section{Data availability}

The data used to support the findings of this study are available from the corresponding author upon request.

\section{Conflicts of interest}

The authors declare that there are no conflicts of interest.

\section{Acknowledgements}

This research was funded by the Tunisian Ministry of Higher Education and Scientific Research through the unit of 
Macromolecular Biochemistry and Genetics, Faculty of Sciences of Gafsa and Laboratory of Environmental Pathophysiology, Development of Bioactive Molecules and Mathematical Modeling, Faculty of Science of Sfax, with collaboration with the Laboratory of Biochemistry at the Regional Hospital of Gafsa, Tunisia.

\section{References}

1 United Nations Industrial Development Organization, What Are Persistent Organic Pollutants (POPs)?, 2015.

2 J. Warner, J. R. Osuch, W. Karmaus, J. R. Landgraf, B. Taffe, M. O'Keefe, D. Mikucki and P. Haan, Common classification schemes for PCB congeners and the gene expression of CYP17, CYP19, ESR1 and ESR2, Sci. Total Environ., 2012, 414, 81-89.

3 X. B. Zheng, X. J. Luo, Y. H. Zeng, J. P. Wu and B. X. Mai, Chiral polychlorinated biphenyls (PCBs) in bioaccumulation, maternal transfer, and embryo development of chicken, Environ. Sci. Technol., 2015, 49, 785-791.

4 J. L. Cai, L. L. Liu, Y. Hu, X. M. Jiang, H. L. Qiu, A. G. Sha, C. G. Wang, Z. H. Zuo and J. Z. Ren, Polychlorinated biphenyls impair endometrial receptivity in vitro via regulating mir-30d expression and epithelial mesenchymal transition, Toxicology, 2016, 365, 25-34.

5 R. E. Ellsworth, K. A. Mamula, N. S. Costantino, B. Deyarmin, P. J. Kostyniak, L. H. Chi, A. S. El-Sharaky, A. A. Newairy, M. A. Kamel and S. M. Eweda, Protective effect of ginger extract against bromobenzene-induced hepatotoxicity in male rats, Food Chem. Toxicol., 2009, 47, 1584-1590.

6 O. Huetos, M. Bartolome, N. Aragones, M. Cervantes-Amat, M. Esteban, M. Ruiz-Moraga and H. A. Jeng, Exposure to endocrine disrupting chemicals and male reproductive health, Front. Public Health, 2014, 2, 55.

7 B. A. Cohn, M. B. Terry, M. Plumb and P. M. Cirillo, Exposure to polychlorinated biphenyl (PCB) congeners measured shortly after giving birth and subsequent risk of maternal breast cancer before age 50, Breast Cancer Res. Treat., 2012, 136, 267-275.

8 J. Kumar, L. Lind, S. Salihovic, B. Van Bavel, E. Ingelsson and P. M. Lind, Persistent organic pollutants and liver dysfunction biomarkers in a population based human sample of men and women, Environ. Res., 2014, 134, 251256.

9 J. Kumar, L. Lind, S. Salihovic, B. Van Bavel, K. N. Ekdahl, B. Nilsson, L. Lind and E. Ingelsson, Influence of persistent organic pollutants on the complement system in a population-based human sample, Environ. Int., 2014, 71, 94-100.

10 L. Passatore, S. Rossetti, A. A. Juwarkar and A. Massacci, Phytoremediation and bioremediation of polychlorinated biphenyls (PCBs): state of knowledge and research perspectives, J. Hazard. Mater., 2014, 278, 189-202.

11 X. N. Wu, M. Duffel and H. J. Lehmler, Oxidation of polychlorinated biphenyls by liver tissue slices from phenobarbital-pretreated mice is congener-specific and atropselective, Chem. Res. Toxicol., 2013, 26(11), 1642-1651.

12 G. S. Zhai, H. J. Lehmler and J. L. Schnoor, Inhibition of cytochromes P450 and the hydroxylation of 4monochlorobiphenyl in whole poplar, Environ. Sci. Technol., 2013, 47, 6829-6835.

13 J. Rezek, T. Macek, M. Mackova, J. Triska and K. Ruzikova, Hydroxy-PCBs, methoxy-PCBs and hydroxy-methoxy-PCBs: metabolites of polychlorinated biphenyls formed in vitro by tobacco cells, Environ. Sci. Technol., 2008, 42, 5746-5751.

14 I. A. T. M. Meerts, Y. Assink, P. H. Cenijn, J. H. J. Van den Berg, B. M. Weijers, A. Bergman, J. H. Koeman and A. Brouwer, Placental transfer of a hydroxylated polychlorinated biphenyl and effects on fetal and maternal thyroid hormone homeostasis in the rat, Toxicol. Sci., 2002, 68, 361-371.

15 H. A. Jeng, Exposure to endocrine disrupting chemicals and male reproductive health, Front. Pub. Health., 2014, 2, 55.

16 P. Venkataraman, R. Muthuvel, G. Krishnamoorthy, A. Arunkumar, M. Sridhar, N. Srinivasan, K. Balasubramanian, M. M. Aruldhas and J. Arunakaran, PCB (Aroclor 1254) enhances oxidative damage in rat brain regions: protective role of ascorbic acid, NeuroToxicology, 2007, 28(3), 490-498.

17 W. J. Xie, A. P. Chen, J. Y. Li, Q. Liu, H. J. Yang, T. Wu and Z. H. Lu, Topsoil dichlorodiphenyltrichloroethane and polychlorinated biphenyl concentrations and sources along an urban-rural gradient in the Yellow River Delta, $J$. Environ. Sci., 2012, 24, 1655-1661.

18 O. Faroon and P. Ruiz, Toxicological profile for polychlorinated biphenyls ( $p c b s$ ) (addendum), US Department of Health and Human Services, Public Health Service, Agency for Toxic Substances and Disease Registry ATSDR, 2011.

19 V. A. Venkatesha, S. Venkataraman, E. H. Sarsour, A. L. Kalen, G. R. Buettner, L. W. Robertson, H. J. Lehmler and P. C. Goswami, Catalase ameliorates polychlorinated biphenyl-induced cytotoxicity in nonmalignant human breast epithelial cells, Free Radicals Biol. Med., 2008, 45, 1094-1102.

20 G. Krishnamoorthy, P. Venkataraman, A. Arunkumar, R. C. Vignesh, M. M. Aruldhas and J. Arunakaran, Ameliorative effect of vitamins ( $\alpha$-tocopherol and ascorbic acid) on PCB (Aroclor 1254) induced oxidative stress in rat epididymal sperm, Reprod. Toxicol., 2007, 23, 239-245.

21 J. Pincemail, K. Bonjean, K. Cayeux and J. O. Defraigne, Mécanismes physiologiques de la défense antioxydante, Nutr. Clin. Metab., 2002, 16, 233-239.

22 B. Wahlang, J. T. Perkins, M. C. Petriello, J. B. Hoffman, A. J. Stromberg and B. Hennig, A compromised liver alters polychlorinated biphenyl-mediated toxicity, Toxicology, 2017, 380, 11-22.

23 R. Haag, G. Scheu, L. Warngard and R. Fransson-Steen, Analysis of rat Gronlund M., Conolly liver foci growth with a quantitative two-cell model after treatment with 2,4,5,3',4'-pentachlorobiphenyl, Toxicol. Sci., 2000, 57(1), 32-42. 
24 G. Ludewig, L. Lehmann, H. Esch and L. W. Robertson, Metabolic activation of PCBs to carcinogens in vivo a review, Environ. Toxicol. Pharmacol., 2008, 25(2), 241-246.

25 C. Maddox, B. Wang, P. A. Kirby, K. Wang and G. Ludewig, Mutagenicity of 3-methylcholanthrene, Pcb3, and 4-OhPcb3 in the lung of transgenic bigblue rats, Environ. Toxicol. Pharmacol., 2008, 25(2), 260-266.

26 G. H. Park, J. H. Park, H. M. Song, H. J. Eo, M. K. Kim, J. W. Lee, M. H. Lee, K. H. Cho, J. R. Lee, H. J. Cho and J. B. Jeong, Anti-cancer activity of Ginger (Zingiber officinale) leaf through the expression of activating transcription factor 3 in human colorectal cancer cells, BMC Complement, BMC Complementary Altern. Med., 2014, $14,8$.

27 M. Thomson, R. Corbin and L. Leung, Effects of ginger for nausea and vomiting in early pregnancy: a metal-analysis, J. Am. Board Fam. Med., 2014, 27(1), 115-122.

28 H. Y. Young, Y. L. Luo, H. Y. Cheng, W. C. Hsieh, J. C. Liao and W. H. Peng, Analgesic and anti-inflammatory activities of [6]-gingerol, J. Ethnopharmacol., 2005, 96(1-2), 207-210.

29 Y. Masuda, H. Kikuzaki, M. Hisamoto and N. Nakatani, Antioxidant properties of gingerol related compounds from ginger, BioFactors, 2004, 21(1-4), 293-296.

30 S. H. Lee, M. Cekanova and S. J. Baek, Multiple mechanisms are involved in 6-gingerol-induced cell growth arrest and apoptosis in human colorectal cancer cells, Mol. Carcinog., 2008, 47(3), 197-208.

31 S. K. Verma, M. Singh, P. Jain and A. Bordia, Protective effect of ginger, Zingiber officinale Rosc. on experimental atherosclerosis in rabbits, Indian J. Exp. Biol., 2004, 42(7), 736-738.

32 V. L. Singleton and J. A. Rossi, Colorimetry of total phenolics with phosphomolybdic-phosphotungstic acid reagents, Am. J. Enol. Vitic., 1965, 16, 144-153.

33 A. Djeridane, M. Yousfi, B. Nadjemi, D. Boutassouna, P. Stocker and N. Vidal, Antioxidant activity of some Algerian medicinal plants extracts containing phenolic compounds, Food Chem., 2006, 97(4), 654-660.

34 D. Heimler, P. Vignolini, M. G. Dini, F. Vincieri and A. Rmani, Antiradical activity and polyphenol composition of local Brassicaceae edible varieties, Food Chem., 2006, 99(3), 464-469.

35 I. Grzegorczyk, A. Matkowski and H. Wysokinska, Antioxidant activity of extracts from in vitro cultures of Salvia officinalis L, Food Chem., 2007, 104, 536-541.

36 Y. H. Chu, C. L. Chang and H. F. Hsu, Flavonoid content of several vegetables and their antioxidant activity, J. Sci. Food Agric., 2000, 80, 561-566.

37 M. A. Shalaby and A. R. Hamowieh, Safety and efficacy of Zingiber officinale roots on fertility of male diabetic rats, Food Chem. Toxicol., 2010, 48, 2920-2924.

38 R. Roos, P. L. Andersson, K. Halldin, H. Hakansson, E. Westerholm, T. Hamers, G. Hamscher, P. Heikkinen, M. Korkalainen, H. A. Leslie, M. Niittynen, S. Sankari, H.-J. Schmitz, L. T. M. Van der Ven, M. Viluksela and D. Schrenka, Hepatic effects of a highly purified $2,2^{\prime}, 3,4,4^{\prime}, 5,5^{\prime}$-heptachlorbiphenyl (PCB 180) in male and female rats, Toxicology, 2011, 284, 42-53.

$39 \mathrm{~K}$. Yagi, A simple fluorometric assay for lipoperoxide in blood plasma, Biochem. Med., 1976, 15, 212-216.

$40 \mathrm{H}$. Aebi, Catalase in vitro, Methods Enzymology, ed. H. U. Bergneyer, 1984, vol. 105, pp. 121-126.

41 I. Durak, Z. Yurtarslani, O. Canbolat and O. Akyol, A methodological approach to superoxide dismutase (SOD) activity assay based on inhibition of nitroblue tetrazolium (NBT) reduction, Clin. Chim. Acta, 1993, 214, 103-104.

42 L. Flohe and W. A. Gunzler, Assays of glutathione peroxidase, Methods Enzymol., 1984, 105, 114-121.

43 O. H. Lowry, N. J. Rosebrough, A. L. Farr and R. J. Randall, Protein measurement with the folin phenol reagent, J. Biol. Chem., 1951, 193, 265-275.

44 M. Gabe, Techniques Histologiques, Masson et Cie, Paris, 1968.

45 I. Lai, Y. Chai, D. Simmons, G. Luthe, M. C. Coleman, D. Spitz, W. M. Haschek, G. Ludewig and L. W. Robertson, Acute toxicity of 3,3',4,4',5-pentachlorobiphenyl (PCB 126) in male Sprague-Dawley rats: effects on hepatic oxidative stress, glutathione and metals status, Environ. Int., 2009, 36(8), 918-923.

46 C. Pereira and C. V. Rao, Combined and individual administration of diethyl phthalate and polychlorinated biphenyls and its toxicity in female Wistar rats, Environ. Toxicol. Pharmacol., 2006, 21, 93-102.

47 Y. Wang, C. Lu, Z. Sheng, G. Liu, Z. Fu, B. Zhu and S. Peng, Enhanced hepatotoxicity induced by repeated exposure to polychlorinated biphenyls and 2,3,7,8-tetrachlorodibenzop-dioxin in combination in male rats, J. Environ. Sci., 2011, 23(1), 119-124.

48 A. S. El-Sharaky, A. A. Newairy, M. A. Kamel and S. M. Eweda, Protective effect of ginger extract against bromobenzeneinduced hepatotoxicity in male rats, Food Chem. Toxicol., 2009, 47(7), 1584-1590.

49 K. Mallikarjuna, C. P. Sahitya, R. K. Sathyavelu and W. Rajendra, Ethanol toxicity: rehabilitation of hepatic antioxidant defense system with dietary ginger, Fitoterapia, 2008, 79, 174-178.

50 T. A. Ajith, U. Hema and M. S. Aswathy, Zingiber officinale Roscoe prevents acetaminophen-induced acute hepatotoxicity by enhancing hepatic antioxidant status, Food Chem. Toxicol., 2007, 45, 2267-2272.

51 O. K. Yemitan and M. C. Izegbu, Protective Effects of Zingiber officinale (Zingiberaceae) against carbon tetrachloride and acetaminophen-induced hepatotoxicity in rats, Phytother. Res., 2006, 20, 997-1002.

52 Z. Shirdel, R. Mirbadalzadeh and H. Madani, Antidiabetic and antilipidemic effect of ginger in alloxan monohydrate diabetic rats in comparison with glibenclamide, Iran. J. Diabetes Lipid Disord., 2009, 9, 7-15.

53 A. Kalaiselvi, G. AadhinathReddy and V. Ramalingam, Ameliorating effect of ginger extract (Zingiber officinale roscoe) on liver marker enzymes, lipid profile in aluminium chloride induced male rats, Int. J. Pharm. Sci. Drug Res., 2015, 7(1), 52-58. 
54 G. H. Heeba and M. I. Abd-Elghany, Effect of combined administration of ginger (Zingiber officinale Roscoe) and atorvastatin on the liver of rats, Phytomedicine, 2010, 17(14), 1076-1081.

55 T. Arablou, N. Aryaeian, M. Valizadeh, A. Hosseini and M. Djalali, The effect of ginger consumption on some cardiovascular risk factors in patients with type 2 diabetes mellitus, Razi J. Med. Sci., 2014, 21(118), 1-12.

56 T. Arablou, N. Aryaeian, M. Valizadeh, F. Sharifi, A. Hosseini and M. Djalali, The effect of ginger consumption on glycemic status, lipid profile and some inflammatory markers in patients with type 2 diabetes mellitus, Int. J. Food Sci. Nutr., 2014, 65(4), 6.

57 H. Gao, T. Guan, C. Li, G. Zuo, J. Yamahara, J. Wang and Y. Li, Treatment with ginger ameliorates fructose-induced fatty liver and hypertriglyceridemia in rats: modulation of the hepatic carbohydrate response element-binding protein-mediated pathway, J. Evidence-Based Complementary Altern. Med., 2012, DOI: 10.1155/2012/ 570948.

58 K. R. Shanmugam, K. Mallikarjuna, N. Kesireddy and K. S. Reddy, Neuroprotective effect of ginger on antioxidant enzymes in streptozotocin-induced diabetic rats, Food Chem. Toxicol., 2011, 49, 893-897.

59 T. P. Twaroski, M. L. O'Brien, N. Larmonier, H. P. Glauert and L. W. Rorbertson, Polychlorinated biphenyls-induced effects of metabolic enzymes, AP-1 binding, vitamin E, and oxidative stress in the rat liver, Toxicol. Appl. Pharmacol., 2001, 171, 85-93.

60 D. V. Rajkumar and M. N. A. Rao, Dihydro-gingerone and isoeugenol as inhibitors of lipid peroxidation and as free radical scavengers, Biochem. Pharmacol., 1993, 46, 20672072.

61 R. S. Ahmed, V. Seth, S. T. Pasha and B. D. Banerjee, Influence of dietary ginger (Zingiber officinale Roscoe) on oxidative stress induced by malathion in rats, Food Chem. Toxicol., 2000, 38, 443-450.

62 P. Venkataraman, M. Sridhar, S. Dhanammal, M. R. Vijayababu, N. Srinivasan and J. Arunakaran, Antioxidant role of zinc in PCB (Aroclor 1254) exposed ventral prostate of albino rats, J. Nutr. Biochem., 2004, 15, 608-613.

63 W. S. Chang, Y. H. Chang, F. J. Lu and H. C. Chiang, Inhibitory effects of phenolic on xanthine oxidase, Anticancer Res., 1994, 14, 501-506.

64 S. A. Gabr, A. H. Alghadir and G. A. Ghoniem, Biological activities of ginger against cadmium-induced renal toxicity, Saudi J. Biol. Sci., 2019, 26, 382-389.

65 C. O. Okoli, P. A. Akah, S. V. Nwafor, A. I. Anisiobi, I. N. Ibegbunam and O. Erojikwe, Antiinflammatory activity of hexane leaf extract of Aspilia africana C.D. Adams, J. Ethnopharmacol., 2007, 109(2), 219-225. 